\title{
EFEKTIVITAS PROGRAM KAWASAN RUMAH PANGAN LESTARI (KRPL) DALAM MENDUKUNG KETAHANAN PANGAN RUMAH TANGGA SELAMA PANDEMI DI KOTA KEDIRI
}

\author{
Dellia Ayu Elma Anindya1, Desiana Nuriza Putri ${ }^{\star}$ dan Novi Dwi Priambodo² \\ ${ }^{1}$ Department of Food Technology, Faculty of Agriculture and Animal Husbandry, University of \\ Muhammadiyah Malang, Malang, Indonesia, ${ }^{2}$ Dinas Ketahanan Pangan Kota Kediri \\ ${ }^{1}$ Jurusan Teknologi Pangan, Fakultas Pertanian Peternakan, \\ Universitas Muhammadiyah Malang, Jl. Raya Tlogomas No. 246, Malang, Jawa Timur \\ *Email: desiana@umm.ac.id
}

\begin{abstract}
Abstrak
Program KRPL (Kawasan Rumah Pangan Lestari) menjadi alternatif dalam mewujudkan kemandirian pangan menuju ketahanan pangan rumah tangga selama pandemic Covid-19. Penelitian ini bertujuan untuk mengetahui dampak dari program KRPL terhadap pola pengeluaran pangan rumah tangga, pola konsumsi pangan dan tingkat konsumsi. Data diambil dengan menggunakan kuisioner dan melakukan wawancara di 8 kelompok aktif KRPL di kota Kediri dengan total 80 responden, data dianalisis secara deskriptif dan ditampilkan dalam bentuk tabel. Hasil penelitian menunjukkan $70 \%$ hasil panen diolah untuk kebutuhan pangan dan gizi keluarga dan $38,75 \%$ berpendapat hasil panen dari lahan pekarangan dapat mencukupi kebutuhan pangan. Beberapa faktor penyebab perbedaan hasil panen setiap KRPL seperti luas lahan, kesadaran anggota kelompok, cuaca dan keinginan anggota dalam menanam jenis tanaman. Program KRPL di Kota Kediri memiliki dampak positif terhadap pola konsumsi pangan rumah tangga dan sebagian besar produksi hasil pekarangan atau hasil panen dimanfaatkan untuk konsumsi rumah tangga. Program KRPL di Kota Kediri telah mendukung penguatan ketahanan pangan rumah tangga.
\end{abstract}

Kata kunci : Covid-19, Kemandirian pangan, Ketahanan pangan, KRPL

\begin{abstract}
The KRPL (Sustainable Reserve Food Garden) program is an alternative in realizing food self-sufficiency to achieve food security during the Covid-19 pandemic. This study is to determine the impact of the KRPL program on household food expenditure patterns, food consumption patterns, and consumption levels by using a questionnaire interview method in 8 active KRPL groups in the city of Kediri with a total of 80 respondents, the data were analyzed using descriptive analysis and displayed in tables. The result of this study indicates that as much as $70 \%$ of the harvest in process for the food and nutritional needs of the family, 38.75\% think that the yields from their yards can meet their food needs. The yields of each KRPL are different due to several factors, namely, the area of land, the awareness of group members, the weather, and the desire of the members to plant types of plants. From the amount of harvest, it can be seen that the level of success of the KRPL program has a positive impact on household food consumption patterns. A yard or harvest yields are still dominant for household consumption. This condition supports the main concept of the KRPL program, namely to strengthen household food security.
\end{abstract}

Keywords: Covid-19, Food Independence, Food Security, KRPL

\section{PENDAHULUAN}

Pandemi Covid-19 yang melanda Indonesia sejak bulan Maret 2020 berdampak diberbagai macam aspek kehidupan. Menurut Susanawati (2020), pertanian merupakan salah satu bidang paling terdampak karena berkaitan erat dengan ketahanan pangan nasional. Salah satu cara untuk menghindar dari permasalahan krisis pangan pada masa pandemi yaitu dengan memperkuat ketahanan pangan dengan pemantapan ketahanan pangan tingkat rumah tangga.

Sektor pertanian merupakan kebutuhan sehari-hari unuk memenuhi kebutuhan masyarakat, baik dari segi hasil pertanian pangan dan perkebunan, sayuran dan buah 
buahan, dan peternakan. Dengan mewabahnya Covid-19 masyarakat dituntut untuk meningkatkan imunitas antara lain dengan mengonsumsi makanan bergizi dan beragam. Demikian, kondisi saat ini justru menjadi sebuah dilema bagi sektor pertanian. Meskipun peluang pasar produk pangan tetap terbuka lebar tetapi distribusi hasil pertanian terkendala karena pembatasan sosial berskala besar (PSBB). Hal ini menyebabkan lesunya permintaan dan menurunnya harga produk pertanian dan peternakan di masa panen raya (Muliati, 2020).

Rozaki (2020) menyatakan bahwa pandemi Covid-19 berpengaruh terhadap berbagai aspek kehidupan manusia, terutama yang bertempat tinggal di area lockdown. Hal ini karena, pemerintah telah menerapkan PSBB (Pembatasan Sosial Berskala Besar) di beberapa daerah yang berdampak pada kebebasan masyarakat dalam melakukan kegiatan di ruang public. Hal ini berdampak pada produksi, distribusi, dan juga konsumsi pangan. Dengan adanya pembatasanpembatasan, distribusi pangan menjadi terhambat dan berakibat stok pangan tidak merata diberbagai daerah, seperti beberapa daerah mengalami defisit dan terdapat daerah dengan angka produksi yang berlebih (Susanawati, 2020). Simanjuntak \& Erwinsyah (2020) melaporkan defisit terjadi pada beberapa komoditas seperti cabai, gula, bawang putih dan telur ayam di lebih dari 20 provinsi, dan tujuh provinsi mengalami defisit beras dan makanan pokok.

Masyarakat memiliki peluang besar dalam membangun kedaulatan dan kemandirian pangan guna mewujudkan ketahanan pangan untuk menghindari terjadinya krisis pangan. (Susanawati, 2020) menyatakan dalam masa pandemi, masyarakat dituntut menjadi lebih kreatif untuk melakukan penanaman mandiri minimal untuk memenuhi kebutuhan pangan rumah tangga. Penanaman mandiri dapat dilakukan dengan metode urban farming dan hidroponik dengan memanfaatkan pekarangan kosong yang ada di sekitar rumah.
Program KRPL merupakan upaya pemerintah bersama dengan Kementerian Pertanian untuk meningkatkan ketahanan pangan dan gizi keluarga (Sholehah, Irawati and Sueb, 2016). Program KRPL diharapkan dapat menjadi alternatif untuk mewujudkan kemandirian pangan, hal ini karena program berupaya memberdayakan dan memanfaatkan sumber daya yang tersedia di sekeliling masyarakat (Atmadja dkk., 2020). Saat ini, terdapat sekitar $70 \%$ kabupaten telah memiliki model KRPL. Kajian Purwantini dkk (2016) menyatakan bahwa hasil pemanfaatan pekarangan di Dusun Jelok, Desa Kayen, Kabupaten Pacitan diolah untuk memenuhi kebutuhan pangan rumah tangga dan memberikan kontribusi rata-rata 53\% dibandingkan dengan desa non peserta Program M-KRPL.

Penelitian ini bertujuan untuk mengetahui efektivitas dari program KRPL di Kota Kediri terhadap pola pengeluaran pangan rumah tangga, pola konsumsi pangan dan tingkat konsumsi selama pandemi di Kota Kediri.

\section{BAHAN DAN METODE}

Penelitian ini menggunakan kuisioner dan wawancara untuk pengambilan data Lokasi penelitian adalah di 8 kelompok KRPL di kota Kediri yang dipilih berdasarkan keaktifan kelompok dalam mengikuti program, dipilih sebanyak 10 responden setiap kelompok secara acak. Data yang digunakan adalah data primer dan sekunder tentang identitas responden, kondisi lahan dan system produksi yang diterapkan.

Data yang diperoleh dalam penelitian ini dianalisis secara deskriptif. Data selanjutnya ditabulasi sesuai kelompok data masingmasing.

\section{HASIL DAN PEMBAHASAN Karakteristik Responden}

Distribusi jenis kelamin anggota KRPL didominasi oleh perempuan, yaitu sebesar $97,5 \%$ (Tabel 1), hal ini karena perempuan memiliki peran aktif dalam membantu aktivitas 
usaha tani dan mencari nafkah di subsektor off dan non-farm. Semakin luas lahan usaha tani yang digarap, semakin besar jumlah tenaga atau waktu wanita yang tercurah. Tingkat ekonomi suatu rumah tangga petani yang semakin rendah, maka semakin besar curahan waktu/tenaga dalam menghasilkan pendapatan keluarga (Waliyah, 2018).

Tabel 1. Karakteristik responden berdasarkan jenis kelamin responden

\begin{tabular}{cccc}
\hline NO & $\begin{array}{c}\text { Jenis } \\
\text { Kelamin }\end{array}$ & $\begin{array}{c}\text { Jumlah } \\
\text { (Orang) }\end{array}$ & $\begin{array}{c}\text { Persentase } \\
\text { (\%) }\end{array}$ \\
\hline 1. & Perempuan & 78 & 97,5 \\
2. & Laki-laki & 2 & 2,5 \\
\hline & Jumlah & 80 & 100 \\
\hline
\end{tabular}

Sumber : Data diolah dari hasil survei, 2020

Mayoritas responden sebanyak 97,5\% adalah perempuan, mereka berpendapat bahwa dalam melaksanakan program kegiatan KRPL dilaksanakan oleh satu pihak saja yaitu perempuan. Hasil ini sesuai dengan penelitian (Rahma and Amanah, 2020) bahwa perempuan menjadi pihak yang paling mendominasi dalam melakukan kegiatan penanaman pekarangan. Perempuan memiliki peran penuh dalam program KRPL karena anggapan masyarakat bahwa program tersebut hanya dijalankan oleh ibu-ibu Kelompok Wanita Tani saja, sementara laki-laki lebh bekerja di luar rumah.

Atmadja dkk (2020) menyatakan terdapat perbedaan peran antara laki-laki dan perempuan dalam rumah tangga, hal ini karena pada dasarnya tingkat kemampuan tenaga antara laki-laki dan perempuan sangat berbeda dan faktor ekonomi dapat mengubah peranana seorang perempuan yang awalnya hanya ibu rumah tangga harus bekerja untuk memenuhi kebutuhan rumah tangganya.

Rentang usia seluruh responden tergolong produktif yaitu umur 20 tahun sd 36 tahun (Tabel 2). Hal ini sesuai dengan pernyataan Oka dkk (2016) bahwa seseorang dengan umur produktif akan lebih cepat dan lebih mudah untuk menerima inovasi baru.
Tabel 2. Karakteristik responden berdasarkan usia responden

\begin{tabular}{cccc}
\hline NO & $\begin{array}{c}\text { Usia } \\
\text { Responden }\end{array}$ & $\begin{array}{c}\text { Jumlah } \\
\text { (Orang) }\end{array}$ & $\begin{array}{c}\text { Persentase } \\
\text { (\%) }\end{array}$ \\
\hline 1. & $<20$ tahun & 1 & 1,25 \\
2. & $21-35$ tahun & 13 & 16,25 \\
3. & $>36$ tahun & 66 & 82,5 \\
\hline & Jumlah & 80 & 100
\end{tabular}

Sumber : Data diolah dari hasil survei, 2020.

Latar belakang pendidikan formal responden terbanyak adalah cukup tinggi yaitu SMA sebesar 32,5\% (Tabel 3). Menurut Oka, I., Darmawan, Dwi., Astiti, (2016) tingkat adopsi inovasi dipengaruhi oleh pendidikan, seseorang dengan tingkat pendidikan yang tinggi akan cenderung tertarik mencoba hal-hal baru dan lebih terbuka dalam menerima ilmu baru.

Tabel 3. Distribusi responden berdasarkan indicator pendidikan

\begin{tabular}{cccc}
\hline NO & Pendidikan & $\begin{array}{c}\text { Jumlah } \\
\text { (Orang) }\end{array}$ & $\begin{array}{c}\text { Persentase } \\
(\%)\end{array}$ \\
\hline 1. & SD & 21 & 26,25 \\
2. & SMP & 22 & 27,5 \\
3. & SMA & 26 & 32,5 \\
4. & Diploma & 2 & 2,5 \\
5. & Sarjana & 9 & 11,25 \\
\hline & Jumlah & 80 & 100
\end{tabular}

Sumber : Data diolah dari hasil survei, 2020

Tingkat Pendidikan yang tinggi berbanding lurus dengan tingkat pengetahuan seseorang dan menjadikan seseorang dapat memahami dan menyelesaikan masalah untuk mencapai tujuan yang ditargetkan. Salah satu aspek penting dalam meningkatkan kualitas SDM yaitu pendidikan. Semakin tinggi tingkat pendidikan seseorang, maka kualitas SDM akan semakin meningkat, baik dari segi pengembangan daya nalar, keterampilan, pengetahuan, wawasan dan analisis. Tingkat pendidikan dapat menentukan kemampuan seseorang dalam mengambil sebuah keputusan dan kemampuan dalam menciptakan sesuatu (Sobron, Titik and Meidawati, 2020) . 
Agrisaintifika

Jurnal Ilmu-Ilmu Pertanian

Vol. 5, No. 1, 2021

Anindya, et al. 2021

Tabel 4. Distribusi responden berdasarkan luas pekarangan

\begin{tabular}{ccccc}
\hline NO & $\begin{array}{l}\text { Kelompok } \\
\text { Lahan }\end{array}$ & $\begin{array}{c}\text { Luas } \\
\text { Pekaran } \\
\text { gan } \\
\left(\mathbf{m}^{2}\right)\end{array}$ & $\begin{array}{c}\text { Jumla } \\
\mathbf{h} \\
(\text { Oran } \\
\mathbf{g})\end{array}$ & $\begin{array}{c}\text { Perse } \\
\text { ntase } \\
(\%)\end{array}$ \\
\hline 1. & $\begin{array}{l}\text { Pekaranga } \\
\text { n sangat }\end{array}$ & $\begin{array}{c}\text { Tanpa } \\
\text { halaman }\end{array}$ & - & - \\
2. & $\begin{array}{l}\text { Pempit } \\
\text { Pekaranga }\end{array}$ & $<120$ & 50 & 62,5 \\
n sempit & $\begin{array}{l}\text { Pekaranga } \\
\text { n sedang }\end{array}$ & $120-400$ & 20 & 25 \\
$4 . \quad \begin{array}{l}\text { Pekaranga } \\
\text { n luas }\end{array}$ & $>400$ & 10 & 12,5 \\
\hline \multicolumn{3}{l}{ Jumlah } \\
\hline Sumber $:$ Data diolah dari hasil survei, 2020
\end{tabular}

Luas pekarangan anggota KRPL tergolong kedalam kelompok lahan pekarangan sempit dengan persentase $62,5 \%$ (Tabel 4). Luas pekarangan menjadi salah satu patokan dalam mengembangkan KRPL, dimana semakin luas lahan pekarangan responden maka pengembangan KRPL yang dilakukan semakin meningkat. Menurut Suputra dkk., (2016), produktivitas lahan berkaitan erat dengan kapasitas lahan dalam menyerap input produksi dan menghasilkan output dalam produksi pertanian.

Berdasarkan rasio RPL dan total lahan pekarangan di Jawa Timur dan Sumatera Selatan, strata sempit merupakan strata optimal dalam optimalisasi pemanfaatan lahan dibandingkan strata lainnya (Hanifah dkk., 2014). Hal ini berarti lahan pekarangan pada strata luas dapat dimanfaatkan sebagai sumber pangan keluarga.

Definisi pekarangan sebagai sumber pangan keluarga menurut (Swardana, 2020) berpendapat fungsi dari pekarangan, yaitu sebagai penghasil bahan makanan, penghasil rempah atau obat, penghasil bahan baku kerajianan dan penghasil bahan bangunan. Berdasarkan fungsi tersebut pekarangan dapat diterapkan untuk memenuhi kebutuhan rumah tangga. Rumah tangga yang mampu mengelola pekarangan dengan baik, selain dapat memenuhi kebutuhan rumah tangganya, tentu dapat meningkatkan ekonomi rumah tangga yang berasal dari penjualan hasil pekarangan.

Tabel 5. Karakteristik responden berdasarkan kecukupan hasil panen dengan kebutuhan panen keluarga

\begin{tabular}{cccc}
\hline NO & $\begin{array}{c}\text { Kategori } \\
\text { Kecukupan }\end{array}$ & $\begin{array}{c}\text { Jumlah } \\
\text { (Orang) }\end{array}$ & $\begin{array}{c}\text { Persentase } \\
(\%)\end{array}$ \\
\hline 1. & Kurang & 24 & 30 \\
2. & Cukup & 31 & 38,75 \\
3. & Sangat cukup & 17 & 21,25 \\
4. & Berlebih & 8 & 10 \\
\hline & Jumlah & 80 & 100 \\
\hline
\end{tabular}

Sumber : Data diolah dari hasil survei, 2020

Sebanyak 38,75\% responden berpendapat hasil panen dari pemanfaatan lahan pekarangan sangat cukup untuk mencukupi kebutuhan pangan keluarga (Tabel 5), sedangkan sebanyak 30\% responden berpendapat bahwa hasil panen kurang mencukupi kebutuhan pangan keluarga kurang hal tersebut disebabkan kurang maksimalnya memanfaatkan pekarangan yang ada untuk menanam berbagai macam sayuran.

Program KRPL merupakan program optimalisasi pemanfaatan pekarangan sebagai penyedia sumber pangan dan sebagai perbaikan gizi rumah tangga. Hasil dari optimalisasi pekarangan ini dapat memberikan kontribusi dalam pemenuhan kebutuhan pangan rumah tangga. Penanaman tanaman di pekarangan yang semakin beragam dapat meningkatkan mutu konsumsi pangan pada rumah tangga dan apabila hasil dari pekarangan berlebihan dapat dijual atau diolah untuk meningkatkan nilai tambah hasil dan pendapatan rumah tangga (Suputra dkk., 2016)

Sebanyak $6,70 \%$ hasil panen program KRPL diolah untuk memenuhi kebutuhan pangan keluarga dan gizi keluarga dan 30\% hasil panen dijual (Tabel 6). Dengan pemanfaatan pekarangan yang lebih intensif maka hasilnya juga bertambah melebihi kebutuhan konsumsi sehingga ada sebagian yang dijual hasil panennya (Wulanjari, 2014). 
Tabel 6. Kategori responden berdasarkan pemanfaatan hasil panen

\begin{tabular}{cccc}
\hline NO & $\begin{array}{c}\text { Kategori } \\
\text { Pemanfaatan }\end{array}$ & $\begin{array}{c}\text { Jumlah } \\
\text { (Orang) }\end{array}$ & $\begin{array}{c}\text { Persentase } \\
\text { (\%) }\end{array}$ \\
\hline 1. & Diolah & 56 & 70 \\
2. & Dijual & 24 & 30 \\
3. & Lainnya & 0 & 0 \\
\hline & Jumlah & 80 & 100
\end{tabular}

Sumber : Data diolah dari hasil survei, 2020

Persentase Pemanfaatan hasil panen di KRPL Kota Kediri lebih besar dibanding KRPL di Kabupaten Pacitan yaitu $53 \%$ hasil pekarangan dimanfaatkan untuk konsumsi rumah tangga dan 24\% untuk dijual. Hal tersebut menujukkan bahwa hasil pekarangan berkontribusi cukup besar untuk konsumsi pangan dan gizi rumah tangga serta berkontribusi untuk mencapai $\mathrm{PPH}$ yang diharapkan (Purwantini dkk., 2016).

Tabel 7. Kategori responden berdasarkan keikutsertaan pelatihan

\begin{tabular}{cccc}
\hline NO & $\begin{array}{c}\text { Kategori } \\
\text { Keikutsertaan }\end{array}$ & $\begin{array}{c}\text { Jumlah } \\
\text { (Orang) }\end{array}$ & $\begin{array}{c}\text { Persentase } \\
(\%)\end{array}$ \\
\hline 1. & Pernah & 65 & 81,25 \\
2. & Tidak pernah & 15 & 18,75 \\
\hline & Jumlah & 80 & 100 \\
\hline
\end{tabular}

Sumber : Data diolah dari hasil survei, 2020

Sebagian besar responden (65\%) pernah mengikuti pelatihan yang dilaksanakan berupa pelatihan cara penanaman yang benar serta pengolahan pangan fungsional (Tabel 7). Pelatihan dilaksanakan di komisariat tiap KRPL atau rumah ketua KRPL yang bertujuan untuk meningkatkan keterampilan dan pengetahuan mengenai konsep KRPL yaitu optimalisasi pemanfaatan lahan pekarangan rumah. Pendidikan non formal adalah pelatihan atau kursus yang diikuti oleh responden.

$$
\text { Beberapa pendekatan seperti }
$$

pendidikan, latihan atau kursus serta penyuluhan telah dilaksanakan oleh dinas ketahanan pangan kota Kediri Pencapaian program KRPL untuk mendukung anggota KRPL dalam meningkatkan usahanya. Hal ini dikarenakan peningkatan pengetahuan anggota tentang perkembangan teknologi, akan berdampak posistif pada produktivitas dan pendapatan, sehingga anggota KRPL mampu meningkatkan kesejahteraannya.

Pengetahuan pertanian dapat diperoleh melalui pendidikan non formal seperti penyuluhan maupun pelatihan atau percobaan dilapangan yang diterima oleh anggota kelompok. Maka dari itu meskipun pendidikan formal yang dimiliki cukup tetapi tidak dibarengi dengan pendidikan non formal yang baik maka tidak mempunyai pengetahuan yang baik terhadap inovasi bidang pertanian. 
Agrisaintifika

Jurnal Ilmu-Ilmu Pertanian

Vol. 5, No. 1, 2021

Anindya, et al. 2021

Tabel 8. Hasil Panen Setiap KRPL Selama Pandemi (Maret-Juli 2020

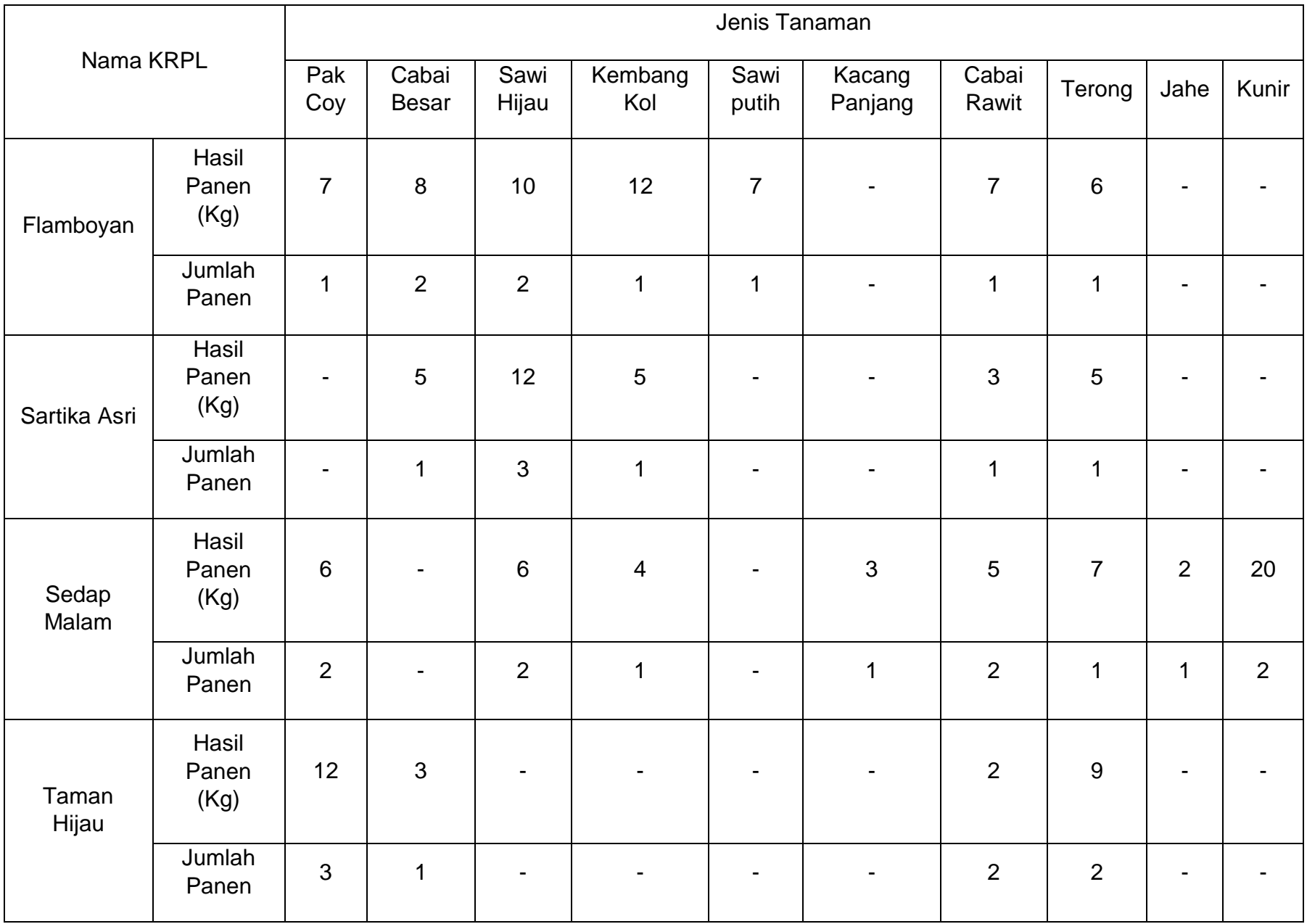

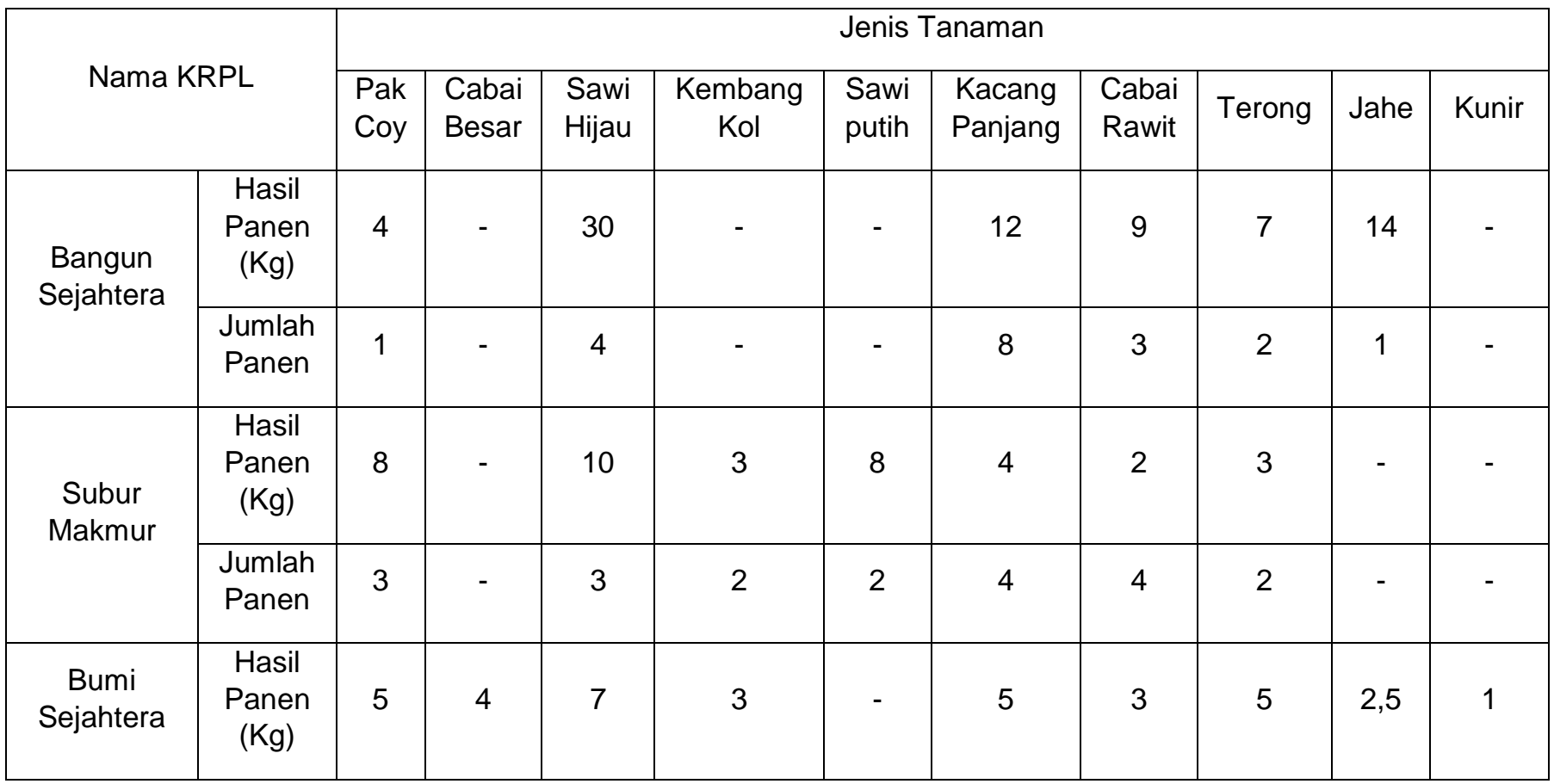


Agrisaintifika

Jurnal Ilmu-Ilmu Pertanian

Vol. 5, No. 1, 2021

Anindya, et al. 2021

\begin{tabular}{|c|c|c|c|c|c|c|c|c|c|c|c|}
\hline & $\begin{array}{c}\text { Jumlah } \\
\text { Panen }\end{array}$ & 2 & 2 & 3 & 1 & - & 2 & 1 & 3 & 1 & 1 \\
\hline \multirow{3}{*}{ Sekartaji } & $\begin{array}{c}\text { Hasil } \\
\text { Panen } \\
(\mathrm{Kg})\end{array}$ & 8 & 2 & 6 & 5 & 3 & 2 & 4 & 7 & 1 & 4 \\
\cline { 2 - 10 } & $\begin{array}{c}\text { Jumlah } \\
\text { Panen }\end{array}$ & 3 & 1 & 2 & 2 & 1 & 1 & 1 & 2 & 1 & 1 \\
\hline
\end{tabular}

Setiap KRPL memiliki hasil panen yang berbeda (Tabel 8), hal ini dikarenakan beberapa faktor seperti luas lahan, kesadaran anggota kelompok dan keinginan anggota dalam menanam jenis tanaman. Jumlah hasil panen anggota program KRPL berkontribusi terhadap peningkatan pendapatan dan peningkatan dalam pemenuhan gizi keluarga. Semakin beragam kelompok komoditas yang ditanam di pekarangan, maka akan semakin beragam pula konsumsi pangan yang berasal dari pekarangan, hal ini menunjukkan bahwa implikasi konsep KRPL dalam diversifikasi pangan yang berbsis sumberdaya lokal tercapai.

Purwantini dkk., (2016) menyatakan bahwa untuk keberlanjutan program KRPL, sangat penting memadukan antara tanamantanaman, ternak dan ikan untuk memenuhi kebutuhan rumah tangga, untuk mencapai itu diperlukan model diversifikasi yang dapat memenuhi kebutuhan beberapa kelompok pangan seperti padi-padian, aneka umbi, pangan hewani, minyak dan lemak, buah/biji berminyak, kacang-kacangan, gula, sayur, dan buah bagi keluarga. Model ini diharapkan dapat memberikan kontribusi pendapatan dan kesejahteraan keluarga.

Tingkat konsumsi rumah tangga anggota KRPL selama pandemi (Tabel 9), meliputi beras sebesar $15-30 \mathrm{~kg}$ per bulan. Tingkat konsumsi mie instan rata-rata tergolong cukup tinggi yaitu 6-10 bungkus per bulan, hal ini karena harganya yang terjangkau dan metode pengolahan yang praktis. Namun demikian, bahan baku dalam pembuatan mie instan yaitu terigu yang berasal dari luar negeri, sehingga untuk menekan ketergantungan terhadap bahan impor, perlu dikembangkan mie berbahan baku umbi-umbi lokal. Selain itu, untuk mengurangi konsumsi beras dalam rangka mendukung program diversifikasi pangan dengan memanfaatkan pangan lokal, KRPL di kota Kediri memiliki potensi dalam mengembangkan pangan lokal seperti berbagai jenis umbi-umbian

Pola konsumsi pangan anggota KRPL Kota Kediri belum dikategorikan seimbang, hal ini karena konsumsi pangan padi-padian masih melebihi standar dan pangan lain seperti tingkat konsumsi pangan hewani dan umbiumbian berada dibawah standar. Beberapa cara untuk meningkatkan antara lain pengembangan jenis pangan tertentu di lahan pekarangan, pengembangan peternakakan seperti Ikan lele, Nila, Ayam Arab, dan Ayam Buras melalui teknologi pembibitan dan budidaya yang baik, serta pengembangan relasi pasarnya (Purwantini dkk., 2016), selain itu perlu adanya sosialisasi mengenai pola konsumsi yang baik dan seimbang kepada seluruh anggota KRPL. 
Agrisaintifika

Jurnal Ilmu-Ilmu Pertanian

Vol. 5, No. 1, 2021

Anindya, et al. 2021

Tabel 9. Jumlah konsumsi pangan setiap KRPL selama satu bulan di masa pandemi.

\begin{tabular}{|c|c|c|c|c|c|c|c|c|}
\hline \multirow{2}{*}{$\begin{array}{c}\text { Jenis } \\
\text { pangan } \\
(\mathrm{Kg})\end{array}$} & \multicolumn{8}{|c|}{ Nama KRPL } \\
\hline & Flamboyan & $\begin{array}{c}\text { Sartika } \\
\text { Asri }\end{array}$ & $\begin{array}{l}\text { Sedap } \\
\text { malam }\end{array}$ & $\begin{array}{c}\text { Taman } \\
\text { hijau }\end{array}$ & $\begin{array}{l}\text { Bangun } \\
\text { sejahtera }\end{array}$ & $\begin{array}{l}\text { Subur } \\
\text { makmur }\end{array}$ & $\begin{array}{c}\text { Bumi } \\
\text { sejahtera }\end{array}$ & Sekartaji \\
\hline Beras & 182 & 195 & 207 & 210 & 285 & 190 & 166 & 150 \\
\hline Jagung & - & - & - & 3 & - & 2 & 18,5 & 2 \\
\hline $\begin{array}{l}\text { Umbi- } \\
\text { umbian }\end{array}$ & 20 & 33 & 34 & 30,5 & 52,5 & 27 & 71 & 63 \\
\hline $\begin{array}{l}\text { Mie instan } \\
\text { (bungkus) }\end{array}$ & 75 & 80 & 68 & 88 & 53 & 81 & 65 & 50 \\
\hline Gula pasir & 17 & 15,5 & 36 & 20,5 & 29 & 25 & 34,5 & 36 \\
\hline Gula merah & 2 & 4,5 & 6 & 3 & 4,75 & 7,5 & 10 & 10 \\
\hline Ikan & 61 & 71 & 21 & 60 & 30 & 21 & 95 & 50 \\
\hline Telur & 41,5 & 171 & 30 & 43,5 & 23 & 23 & 59 & 30 \\
\hline Daging & 9 & 5,5 & 12 & 7 & 18,25 & 19,5 & 6 & 10 \\
\hline $\begin{array}{l}\text { Kacang- } \\
\text { kacangan }\end{array}$ & 6 & 5,5 & 14 & 1,5 & 4,25 & 12 & 9,5 & 7 \\
\hline $\begin{array}{c}\text { Minyak } \\
\text { Goreng (L) }\end{array}$ & 25 & 43 & 36 & 41 & 38 & 28 & 57 & 30 \\
\hline $\begin{array}{l}\text { Sayur- } \\
\text { sayuran }\end{array}$ & 45 & 57 & 30 & 27 & 57 & 41 & 50 & 16 \\
\hline $\begin{array}{l}\text { Bumbu- } \\
\text { bumbuan }\end{array}$ & 17 & 17,5 & 14 & 15 & 21 & 22 & 20,5 & 18 \\
\hline $\begin{array}{l}\text { Buah- } \\
\text { buahan }\end{array}$ & 26 & 61 & 55 & 57 & 44 & 57 & 69 & 38 \\
\hline
\end{tabular}

Sumber : Diolah dari data hasil survei, 2020. 
Masyarakat Indonesia memiliki tingkat konsumsi pangan tergolong masih rendah jika dibanding dengan Negara-negara lain, kecuali beras. (Purwantini dkk, 2016) mengungkapkan perbandingan tingkat komoditas pangan rakyat Indonesia dengan beberapa Negara atau dengan dunia sebagai berikut : (1) Masyarakat Indonesia rata-rata mengkonsumsi ikan 12,5 $\mathrm{Kg}$ perkapita/tahun, sedangkan dunia memiliki rata-rata di atas $16 \mathrm{Kg}$ perkapita pertahun; (2) Penduduk Indonesia rata-rata tingkat konsumsi daging ayam 3,8 $\mathrm{Kg}$ perkapita/tahun, sedangkan Malaysia mencapai $23 \mathrm{Kg}$ perkapita pertahun dan Thailand mencapai $16,8 \mathrm{Kg}$ perkapita pertahun; (3) Tingkat konsumsi buahbuahan masyarakat Indonesia baru sebesar 40,06 Kg perkapita pertahun, sedangkan AS sudah mencapai $75 \mathrm{Kg}$ perkapita pertahun dan standar FAO $65,75 \mathrm{Kg}$ perkapita pertahun; (4) Rata-rata tingkat konsumsi gula $15,6 \mathrm{Kg}$ perkapita pertahun dan rata-rata dunia $25,1 \mathrm{Kg}$ perkapita pertahun; (5) Untuk komoditas kedelai, rata-rata tingkat konsumsi $6,01 \mathrm{Kg}$ perkapita pertahun dan rata-rata dunia $7 \mathrm{Kg}$ perkaita pertahun; (6) Konsumsi rata-rata sayuran masyarakat Indonesia $37,94 \mathrm{Kg}$ perkapita pertahun angka tersebut jauh di bawah anjuran FAO sebesar $65,75 \mathrm{Kg}$ perkapita pertahun; (7) Rata-rata tingkat konsumsi susu rakyat Indonesia masih 6,6 liter perkapita pertahun, sedangkan standar gizi nasional 7,2 liter perkapita pertahun; jauh lebih rendah dari Kamboja yang mencapai 12,97 liter perkapita pertahun, Banglades 31 liter perkapita pertahun, dan India yang telah mencapai 40 liter perkapita pertahun; (8) Untuk telur dan daging, tingkat konsumsi masyarakat Indonesia masing-masing $3,48 \mathrm{Kg}$ dan $7,1 \mathrm{Kg}$ perkapita pertahun, sedangkan di Malaysia rata-rata tingkat konsumsi masing-masing mencapai $17,62 \mathrm{Kg}$ dan 46,87 kg perkapita pertahun dan Filipina mencapai $4,51 \mathrm{Kg}$ dan $24,96 \mathrm{Kg}$ perkapita pertahun. Implikasinya adalah tingkat konsumsi pangan baik sebagai sumber energi maupun sumber protein, serta sumber vitamin dan sumber mineral sangat perlu ditingkatkan, karena hal tersebut menjadi penentu kualitas sumber daya manusia.

\section{SIMPULAN}

Keberhasilan program KRPL di Kota Kediri dipengaruhi oleh beberapa faktor, antara lain potensi sumber daya lahan pekarangan, kapasitas SDM petani dalam mengelola lahan pekarangan, dan penerapan teknologi spesifik lokasi lahan pekarangan.

Program KRPL Kota Kediri berhasil mengurangi pengeluaran rumah tangga untuk konsumsi pangan dan berpengaruh terhadap pola konsumsi pangan rumah tangga. produksi hasil pekarangan / hasil panen. Hasil panen sebagian besar digunakan untuk memenuhi kebutuhan konsumsi rumah tangga yang mendukung penguatan ketahanan pangan rumah tangga.

\section{DAFTAR PUSTAKA}

Atmadja, M., Rangga, Kordiyana ., Listiana, I. and Jurusan (2020) 'Peranan Ibu Rumah Tangga Pada Program Kawasan Rumah Pangan Lestari di Kecamatan Natar Kabupaten Lampung Selatan', 8(1), pp. 176-182. Available at: https://jurnal.fp.unila.ac.id/index.php/JIA/a rticle/view/4334.

Hanifah, Vyta., Marsetyowati, T., Ulpah, A. (2014) 'Fakator-Faktor Yang Mempengaruhi Konsumsi Sayuran Rumah Tangga Pada Kawasan Rumah Pangan Lestari di Provonsi Jawa Timur Dan Sumatera Selatan', 17, pp. 14-153. Available at: http://ejurnal.litbang.pertanian.go.id/index. php/jpengkajian/article/view/1801.

Muliati, N. K. (2020) 'Pengaruh Perekonomian Indonesia di Berbagai Sektor Akibat Corona Virus Disease 2019 (Covid-19)', Widya Akuntansi dan Keuangan, 2(2), pp. 78-86. doi: 10.32795/widyaakuntansi.v2i2.874.

Oka, I., Darmawan, Dwi., Astiti, N. (2016) 'Keberhasilan Program Kawasan Rumah Pangan Lestari (KRPL) pada Kelompok Wanita Tani di Kabupaten Gianyar', Jurnal Manajemen Agribisnis, 4(2), pp. 133-146. 
Purwantini, Tri., S. and Suharyono, S. (2016) 'Program Kawasan Rumah Pangan Lestari (KRPL) di Kabupaten Pacitan: Analisis Dampak dan Antisipasi ke Depan', Analisis Kebijakan Pertanian, 10(3), p. $239 . \quad$ doi: 10.21082/akp.v10n3.2012.239-256.

Purwantini, T. B., Saptana, S. and Suharyono, S. (2016) 'Program Kawasan Rumah Pangan Lestari (KRPL) di Kabupaten Pacitan: Analisis Dampak dan Antisipasi ke Depan', Analisis Kebijakan Pertanian, 10(3), p. $239 . \quad$ doi: 10.21082/akp.v10n3.2012.239-256.

Rahma, A. and Amanah, S. (2020) 'Tingkat Kesetaraan Gender dalam Rumah Tangga Peserta Program Kawasan Rumah Pangan Lestari (KRPL)', Jurnal Sains Komunikasi dan Pengembangan Masyarakat [JSKPM], 4(2), pp. 207-216. doi: 10.29244/jskpm.4.2.207-216.

Rozaki, Z. (2020) 'COVID-19, agriculture, and food security in Indonesia', Reviews in Agricultural Science, 8(October), pp. 243261. doi: 10.7831/ras.8.0_243.

Sholehah, N., Irawati, M. and Sueb, S. (2016) 'Kawasan Rumah Pangan Lestari (KRPL): Analisis Pengetahuan dan Perilaku Santri', JPS (Jurnal Pendidikan Sains), $4(4)$, pp. 152-156.

Simanjuntak, A. H. and Erwinsyah, R. G. (2020) 'Kesejahteraan Petani Dan Ketahanan Pangan Pada Masa Pandemi Covid-19: Telaah Kritis Terhadap Rencana Megaproyek Lumbung Pangan Nasional Indonesia Smallholders Welfare and Food Security in Times of Covid-19 Pandemic: a Critical Review of Indonesia ' S Me', Sosio Informa, 6(2), pp. 184-204.

Sobron, A. N., Titik, S. and Meidawati, S. (2020) 'Jurnal Inovasi Penelitian', Jurnal Inovasi Penelitian, 1(3), pp. 1-4.

Suputra, Gusti., Putra, I., Suardi, I. (2016) 'Evaluasi Dampak Program Kawasan Rumah Pangan Lestari (Krpl) Pada Kelompok Wanita Tani (Kwt) Tunas Sejahtera Di Kecamatan Blahbatuh, Kabupaten Gianyar', E-Journal Agribisnis dan Agrowisata (Journal of Agribusiness and Agritourism), 5(1). Available at: https://media.neliti.com/media/publication s/44924-ID-evaluasi-dampak-programkawasan-rumah-pangan-lestari-krpl-padakelompok-wanita-t.pdf.

Susanawati, S. G. (2020) Ketahanan Pangan Indonesia di Masa Pandemi, Universitas Muhammadiyah Yogyakarta. Available at: https://www.umy.ac.id/ketahanan-panganindonesia-di-masa-pandemi.html.

Swardana, A. (2020) 'Optimalisasi Lahan Pekarangan Sebagai Salah Satu Upaya Pencegahan Krisis Pangan di Masa Pandemi Covid-19', Jagros, 4(2), pp. 246-258.

Waliyah, H. (2018) 'Peran anggota kelompok wanita tani dalam pemanfaatan pekarangan melalui $\mathrm{krpl}$ di desa pucangsari kecamatan purwosari kabupaten pasuruan jawa timur', Jurnal.polbangtanmalang, (2017).

Wulanjari, M. E. (2014) 'Pengembangan Potensi Sumberdaya Lokal Berwawasan Lingkungan untuk Penguatan Produk Pertanian Nasional Berdaya Saing Global', pp. 277-286. Available at: file:///C:/Users/WINDOWS 10/Documents/wulanjari.pdf. 